\title{
PENGARUH KOMUNIKASI PEMASARAN TERPADU TERHADAP NIAT MUZAKKI MEMBAYAR DANA ZAKAT, INFAQ, SHADAQAH PADA YAYASAN NURUL HAYAT CABANG TUBAN
}

\author{
Milla Rahma Fighyany \\ Mahasiswa Program Studi S1 Ekonomi Islam - Fakultas Ekonomi dan Bisnis - Universitas \\ Airlangga \\ Email: millarahmal@gmail.com
}

Ari Prasetyo

Departemen Ekonomi Syariah - Fakultas Ekonomi dan Bisnis - Universitas Airlangga Email: ari_feunair@yahoo.co.id

\begin{abstract}
:
This study aimed to find out the effect of integrated marketing communication which consist of advertising, public relation, direct marketing, and personal selling to muzakki's intention paying zakah, infaq, shadaqah funds at Nurul Hayat Foundation Branch Tuban. Primary data of this research is taken by questionnaires with samples are 98 respondent is taken by simple random sampling. This research uses quantitative approach with multiple linear regresion analysis.

The result of this research showed that integrated marketing communication (advertising, public relation, direct marketing, and personal selling) simultaneously influence muzakki's intention. While partially, only two variables that are advertising and public relation have influence to muzakki's intention. And exogenous variables which is the most dominant influence endogenous is public relation.

Nurul Hayat Foundation branch Tuban should give more attention to each kind of integrated marketing communication, especially personal selling. Beside that, they should give more motivation and training for their employees which work as zakah advisor. For further research, it can be research about marketing mix is done by a kind of the other institution, with the result that will find out more extensive research about factors that influence muzakki pay or distribute zakah, infaq, shadaqah funds at zakah institution.
\end{abstract}

Keywords: integrated marketing communication, advertising, public relation, direct marketing, personal selling, muzakki's intention

\section{PENDAHULUAN}

\section{A. Latar Belakang Masalah}

Kemiskinan merupakan salah satu masalah sosial yang dihadapi oleh masyarakat di sebagian besar wilayah Indonesia. Kemiskinan yang terjadi merupakan akibat adanya berbagai ketimpangan yang lahir dari perilaku masyarakat. Di berbagai ketimpangan itu yang paling mencolok adalah ketimpangan pembagian pendapatan antara masyarakat kaya dan miskin (Muflih, 2006:44). Islam sebagai agama yang rahmatan lil-'alamin telah memberikan tuntunan pada segala aspek kehidupan manusia termasuk aspek sosial ekonomi yang didalamnya terdapat permasalahan kemiskinan. Untuk mengatasi permasalahan tersebut Islam telah memberi solusi melalui instrumen zakat, infaq, dan shadaqah. Menurut Beik (2009) posisi zakat sebagai instrumen pengaman sosial bertugas untuk menjembatani transfer kekayaan dari kelompok kaya kepada kelompok miskin. 
Dalam surat adz-Dzariyaat ayat 19, Allah SWT berfirman:

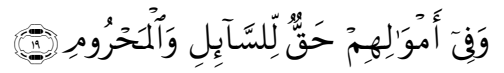

Wafi> 'amwa>lihim h\{aqqul-lissa>'ili walmah\{ru>mi.

"Dan pada harta-harta mereka ada hak untuk orang miskin yang meminta dan orang miskin yang tidak mendapat bagian" (Departemen Agama, 2007:521)

Sebagai negara yang mayoritas penduduknya adalah muslim, Indonesia memiliki potensi zakat yang sangat besar, namun dana zakat yang tekumpul belum sebanding dengan potensi yang ada. Hal ini disebabkan karena kurangnya kesadaran masyarakat berzakat maal, terutama berzakat pada lembaga zakat. Perkembangan pengelolaan zakat melalui lembaga zakat di Indonesia saat ini dapat dikatakan berkembang pesat dengan jumlah lembaga zakat yang berdiri semakin banyak. Zakat yang disalurkan melalui lembaga zakat yang kredibel, bertujuan agar dana zakat yang disalurkan dapat optimal melalui program pemberdayaan yang dapat mengentaskan kemiskinan. Selain itu lembaga zakat pada akhirnya diharapkan dapat menjadi media untuk menjembatani dalam pencapaian potensi zakat di Indonesia, namun fenomena yang terjadi kinerja dari lembaga zakat tersebut kurang maksimal (Fadhilah, dkk, 2012).

Salah satu faktor penyebab kurang maksimalnya kinerja lembaga zakat adalah kurangnya niat umat muslim untuk berzakat di lembaga zakat, serta rendahnya kepercayaan masyarakat terhadap institusi formal pengelola zakat sehingga menyalurkan zakat dengan cara mandiri (Maulana, 2010). Maka dari itu untuk mengatasi fenomena tersebut tugas dari pengelola zakat adalah mengerti dan memahami perilaku muzakki agar dapat menjaring dana dan mendapatkan kepercayaan dari para muzakki.

Bagi lembaga amil zakat manapun, komunikasi memiliki peran penting untuk bersosialisasi dengan masyarakat, khususnya kepada muzakki dan mustahik. Komunikasi yang dimaksud disini adalah komunikasi pemasaran. Tantangan utama dalam pemasaran adalah menarik perhatian orang, yaitu menemukan cara baru untuk menarik perhatian dan menanamkan brand dalam benak setiap orang (Kotler, 2005:117). Menurut Kotler dan Armstrong (2008:116) komunikasi pemasaran atau promosi terdiri dari lima sarana promosi yaitu periklanan, promosi penjualan, hubungan masyarakat, penjualan personal, dan pemasaran langsung yang disebut sebagai bauran komunikasi pemasaran atau bauran promosi. Agar komunikasi pemasaran yang dilakukan berjalan dengan efektif maka segala bentuk komunikasi harus direncanakan dan dipadukan ke dalam program komunikasi pemasaran yang diintegrasikan secara cermat melalui komunikasi pemasaran terpadu (Integrated Marketing CommunicationIMC). Dalam konsep IMC, menurut Kotler dan Armstrong (2008:120) perusahaan secara cermat mengintegrasikan berbagai 
saluran komunikasi untuk menghantarkan pesan yang jelas, konsisten, dan menarik tentang organisasi dan mereknya. Melalui komunikasi pemasaran yang terintegrasi, lembaga zakat dapat menginformasikan, membujuk, dan mengingatkan tentang jasa yang ditawarkan kepada muzakki secara jelas, konsisten, dan menarik yang dapat memotivasi mereka untuk memiliki niat membayar dana zakat, infaq, shadaqah serta dapat membangun kepercayaan muzakki pada lembaga tersebut untuk mengelola dana zakat, infaq, shadaqah untuk program-program pemberdayaan mustahik.

Lembaga zakat yang digunakan dalam penelitian ini adalah Yayasan Nurul Hayat cabang Tuban. Yayasan Nurul Hayat merupakan salah satu lembaga zakat di kabupaten Tuban yang aktif mengadakan kegiatan-kegiatan sosial hampir di sebagian besar wilayah Tuban. Dalam pengembangan dana zakat, infaq, shadaqah Yayasan Nurul Hayat cabang Tuban membentuk jaringan koordinator donatur. Tenaga-tenaga fundraiser (penjemput dana zakat, infaq, shadaqah) dikerahkan untuk pengambilan donasi. Untuk promosi, Yayasan Nurul Hayat cabang Tuban telah menerapkan komunikasi pemasaran terpadu melalui bauran komunikasi pemasaran atau bauran promosi seperti, advertising, public relation, direct marketing dan personal selling. Melalui komunikasi pemasaran terpadu yang dilakukan oleh Yayasan Nurul Hayat cabang Tuban, pihak Yayasan Nurul Hayat bisa lebih dekat dengan donaturnya melalui publikasi program sosial dan dakwahnya dan dapat mempengaruhi niat masyarakat membayar zakat, infaq, dan shadaqah di yayasan tersebut.

Berdasarkan latar belakang di atas maka penelitian ini akan diteliti lebih lanjut tentang pengaruh komunikasi pemasaran terpadu terhadap niat muzakki membayar dana zakat, infaq, shadaqah pada Yayasan Nurul Hayat cabang Tuban.

\section{B. Rumusan Masalah}

Berdasarkan latar belakang di atas, maka rumusan masalah pada peelitian ini adalah:

1. Apakah komunikasi pemasaran terpadu berpengaruh terhadap niat muzakki membayar dana zakat, infaq, shadaqah pada Yayasan Nurul Hayat cabang Tuban baik secara simultan maupun parsial?

2. Variabel komunikasi pemasaran terpadu manakah yang berpengaruh dominan terhadap niat muzakki membayar dana zakat, infaq, shadaqah pada Yayasan Nurul Hayat cabang Tuban?

\section{Tujuan Penelitian}

Adapun tujuan penelitian yang ingin dicapai adalah:

1. Untuk mengetahui dan menganalisa pengaruh komunikasi pemasaran terpadu terhadap niat muzakki membayar zakat, infaq, shadaqah pada Yayasan Nurul Hayat cabang Tuban. 
2. Untuk mengatahui dan menganalisa variabel komunikasi pemasaran terpadu yang berpengaruh dominan terhadap niat muzakki membayar dana zakat, infaq, shadaqah pada Yayasan Nurul Hayat cabang Tuban.

\section{LANDASAN} TEORI

DAN

\section{PENGEMBANGAN HIPOTESIS}

\section{A. Pemasaran dalam Islam}

Pemasaran dalam Islam adalah salah satu bentuk muamalah yang dibenarkan dalam Islam. Pemasaran syariah menurut Kartajaya dan Sula (2006:26) adalah sebuah disiplin bisnis yang mengarahkan proses penciptaan, penawaran, dan perubahan value dari suatu inisiator kepada stakeholder-nya, yang dalam keseluruhan prosesnya sesuai dengan akad dan prinsip-prinsip muamalah (bisnis) dalam Islam.

Terdapat empat karakteristik pemasaran syariah menurut Kartajaya dan Sula (2006:28), yaitu Teistis (Rabbaniyah), Etis (Akhlaqiyyah), Realistis (al-waqi'iyyah), Humanistis (insaniyyah). Sedangkan menurut Muslich (2007:161) Nabi Muhammad dalam berdagang mempunyai tiga konsep prinsip pemasaran menurut Islam, yaitu: Trust, Quality Service, responsibility atau amanah.

\section{B. Komunikasi Pemasaran dalam Islam}

Komunikasi pemasaran menurut Adisaputro (2010:253) adalah suatu alat yang digunakan perusahaan untuk memberitahu, mendesak, dan mengingatkan konsumen, baik secara langsung maupun tidak langsung, tentang produk dan brand yang mereka pasarkan. Dalam Islam, efektivitas komunikasi pemasaran harus menyerap prinsip-prinsip yang terdapat dalam AlQur'an (Rachmad, 2013) Menurut Kartajaya dan Sula (2006:44), Nabi Muhammad SAW adalah seorang pedagang. Beliau dalam memasarkan produk-produknya melakukan transaksitransaksi secara jujur, adil, dan tidak pernah membuat pelanggannya mengeluh dan kecewa.

Kartajaya dan Sula (2006:120) mengatakan bahwa terdapat empat hal yang menjadi key success factors dalam mengelola suatu bisnis, agar mendapat celupan nilai-nilai moral yang tinggi. Keempat hal tersebut adalah sifat-sifat yang dimiliki oleh Nabi Muhammad SAW Shiddiq (benar dan jujur), Amanah (terpecaya, kredibel), Fathanah (cerdas), Tabligh (komunikatif).

\section{Komunikasi Pemasaran Terpadu dalam Islam}

Konsep komunikasi pemasaran terpadu menurut Kotler dan Armstrong (2008:120) adalah mengintegrasikan dan mengkoordinasikan berbagai saluran komunikasi perusahaan untuk menghantarkan pesan yang jelas, konsisten, dan menarik tentang organisasi dan produknya. Menurut Kotler \& Amstrong (2004:605) dalam Nasiha (2010:2), IMC dapat menyatukan semua pesan dan citra perusahaan. Dalam konsep ini, perusahaan harus bisa 
mengkoordinasikan alat-alat komunikasi pemasaran agar bisa bekerja bersamasama. Saling mendukung satu sama lain sehingga bisa saling melengkapai dalam mencapai target audiens yang diinginkan. Hal ini sesuai dengan apa yang terkandung dalam surat Al-Ma'idah ayat 2:

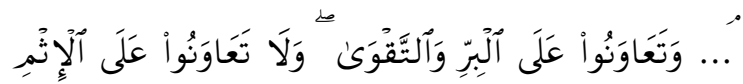

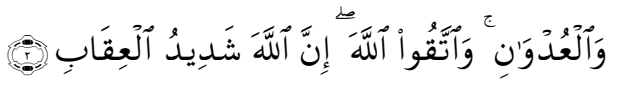

....wata'a>nu> 'alal-lbirri wat-taqwa>, wala $>$ ta' $a>$ wanu> 'alal-is\{mi wal-'udwan, wattaqul-lla $>$ ha innal-lla $>$ ha syadi $>$ dul'iqa>b.

"Dan tolong-menolonglah kamu dalam (mengerjakan) kebajikan dan takwa, dan jangan tolong-menolong dalam berbuat dosa dan pelanggaran. dan bertakwalah kamu kepada Allah, Sesungguhnya Allah Amat berat siksa-Nya" (Departemen Agama, 2007:106).

Melalui ayat tersebut dapat kita telah bahwa saling menolong dan bekerja bersama-sama dalam melakukan suatu hal dengan tujuan yang baik maka akan berdampak besar terhadap pencapaiannya. Di samping itu, bekerja secara bersama-sama dapat meringankan tugas dan tanggung jawab yang telah diemban (Nasiha, 2010:2).

\section{Bauran Komunikasi Pemasaran Islam}

Dalam Islam, kegiatan dari bauran promosi harus dijalankan sesuai dengan ajaran-ajaran Islam. Pada saat Nabi Muhammad SAW berbisnis dalam mengkomunikasikan bisnisnya, beliau juga menggunakan alat-alat promosi atau bauran promosi tersebut, dan konsepnya tidak terlepas dari nilai moralitas dan etika keislaman (Asmaniah, 2007:49). Bauran promosi atau bauran komunikasi pemasaran di antaranya adalah sebagai berikut:

1. Iklan (advertising) yaitu segala bentuk presentasi non personal dan promosi gagasan, barang, atau jasa oleh sponsor tertentu yang harus dibayar (Kotler, 2005:277). Periklalan dalam Islam harus sesuai dengan ajaran Islam. Menurut Miftah Faridl (Sula, 2004:475) dalam Sari (2009) mengatakan bahwa Rasulullah SAW sangat melarang promosi yang dilakukan secara berlebih-lebihan dan menyembunyikan kekurangan dan cacat barang, karena hal itu akan mengurangi nilai keberkahannya.

2. Promosi penjualan (sales promotion), yaitu berbagai kumpulan alat-alat insentif, yang sebagian besar berjangka pendek, yang dirancang untuk meransang pembelian produk atau jasa tertentu dengan lebih cepat dan lebih besar oleh konsumen (Kotler, 2005:298). Dalam Islam, pemberian insentif dalam promosi penjualan diperbolehkan asalkan tidak mengandung hal-hal yang terlarang seperti : kedhaliman, riba, gharar, penipuan, dan lain-lain. Misalnya pengadaan undian, jika undian yang dilaksanan adalah undian tanpa syarat maka hukumnya boleh, namun 
jika undian tersebut memerlukan syarat dan mengeluarkan biaya maka hukunya haram dan tidak boleh (Hendratmi, 2013).

3. Public Relation, menurut Tom Harris (Machfoedz, 2010:41) hubungan masyarakat pemasaran merupakan proses perencanaan, pelaksanaan, dan evaluasi program yang memotivasi pembelian dan kepuasan konsumen melalui komunikasi informasi yang dapat dipercaya dan kesan yang mengidentifikasikan perusahaan dan produknya dengan kebutuhan dan keinginan, kepedulian dan minat konsumen. Dalam Islam, Rasulullah SAW dalam melakukan kegiatan pemasaran, beliau selalu membangun silaturahim atau membangun relasi dengan para konsumennya (Suyanto:2008)

4. Pemasaran langsung (direct marketing), yaitu penggunaan saluran-saluran langsung konsumen untuk menjangkau dan menyerahkan barang dan jasa kepada pelanggan tanpa menggunakan perantara pemasaran, saluran-saluran tersebut adalah direct mail, katalog, telemarketing, dan sebagainya (Kotler, 2005:311). Payne (2001:203) mengatakan bahwa perkembangan dalam media elektronik, telekomunikasi dan komputer menghadirkan peluang yang lebih besar untuk mengembangkan program kegiatan direct marketing, ini dapat digunakan dalam hubungannya satu sama lain untuk memperkuat penjualan personal dan unsur promosi lain.

5. Penjualan personal (personal selling) adalah improvisasi dari penjualan dengan menggunakan komunikasi person to person communication (Soemanagara, 2006:4). Dalam Islam, para tenaga penjual merupakan ujung tombak perusahaan dalam menjalin relasi dengan pelanggan. Tenaga penjual juga banyak memberikan informasi umpan balik mengenai pelanggan (Firmansyah:2012). Strategi promosi yang dilakukan oleh Rasulullah SAW yang meliputi berpenampilan menawan, membangun relasi, mengutamakan keberkahan, memahami pelanggan, mendapatkan kepercayaan, memberikan pelayanan hebat, berkomunikasi, menjalin hubungan yang bersifat pribadi, tanggap terhadap permasalahan, menciptakan perasaan satu komunitas, berintegrasi, menciptakan keterlibatan dan menawarkan pilihan (Suyanto:2008).

\section{E. Perilaku Konsumen Islam}

Perilaku konsumen menurut Kotler dan Keller (2008:166) adalah studi tentang bagaimana individu, kelompok dan organisasi memilih, membeli, menggunakan dan bagaimana barang, jasa, ide, atau pengalaman untuk memuaskan kebutuhan dan keinginan 
mereka. Sedangkan dalam Islam, perilaku seorang konsumen harus mencerminkan hubungan dirinya dengan Allah SWT. Setiap pergerakan dirinya yang berbentuk belanja sehari-hari tidak lain adalah manifestasi dirinya atas nama Allah. (Muflih, 2006:4)

Menurut Mokhlis (2009) dalam Alam (2011), agama merupakan faktor budaya yang penting karena agama adalah salah satu lembaga sosial yang paling universal dan berpengaruh signifikan terhadap sikap, nilai dan perilaku masyarakat baik di tingkat individu dan sosial. Alam (2011) mengatakan bahwa orang yang memiliki agama memegang nilai-nilai tertentu yang dapat mempengaruhi tindakan dan keputusan mereka dalam bertindak.

Menurut Schifman dan Kanuk (2010:483) dalam (Maisya,2013) terdapat beberapa faktor yang mempengaruhi keputusan pembelian, diantaranya:

a. Bauran pemasaran adalah paduan unik dari produk, distribusi, promosi, dan strategi harga yang dirancang untuk menghasilkan hubungan yang saling menguntungkan dengan target market.

b. Lingkungan sosial-budaya meliputi keluarga, kelompok referensi, sumber non-komersial, kelas sosial, dan subbudaya.

c. Psikologis konsumen. Proses keputusan pembelian dipengaruhi oleh unsur psikologis yang menentukan tipe pembelian yang dibuat oleh konsumen. Unsur-unsur psikologis tersebut meliputi motivasi, persepsi, pembelajaran, kepribadian, dan sikap.

\section{F. Niat Beli Konsumen dalam Islam}

Menurut Assael (2002) dalam Yudhiartika dan Haryanto (2012) mendefinisikan niat beli sebagai kecenderungan konsumen untuk membeli suatu merek atau mengambil tindakan yang berhubungan dengan pembelian yang diukur dengan tingkat kemungkinan konsumen melakukan pembelian. Anoraga (2007:228) dalam Prasetyo (2013) mendefinisikan niat beli merupakan suatu proses pengambilan keputusan yang dilakukan oleh pelanggan atas produk yang ditawarkan atau yang dibutuhkan oleh pelanggan.

Menurut Kotler dan Armstrong (2008:124) terdapat enam tahapan yang biasa dilalui konsumen dalam proses melakukan pembelian, yaitu kesadaran, pengetahuan akan produk dan jasa, rasa suka terhadap produk dan jasa, preferensi yaitu lebih menyukai produk atau jasa tersebut dibanding dengan lainnya, keyakinan yaitu percaya bahwa produk dan jasa itu adalah yang terbaik, dan kemudian memutuskan untuk melakukan pembelian.

Dalam ilmu ekonomi Islam, keputusan pembelian konsumen Muslim menerapkan konsep mashlahah. Pada konsep mashlahah ditemukan adanya Sikap hemat, membatasi diri pada barang yang halal, dan prioritas terhadap kebutuhan pokok (Muflih, 2006:94). 
Teori mashlahah menggambarkan motif kesederhanaan individu pada setiap bentuk keputusan konsumsinya. Dalam hal ini, karena mashlahah bertujuan melahirkan manfaat, persepsi yang ditentukannya adalah konsumsi yang sesuai dengan kebutuhan. Konsep mashlahah tidak selaras dengan kemudharatan, itulah sebabnya dia melahirkan persepsi yang menolak kemudharatan seperti barang-barang yang haram, termasuk bentuk konsumsi yang mengabaikan kepentingan orang lain. Niat dalam mendapatkan manfaat ini disemangati oleh persepsi tentang mardhatillah yang kemudian mendorongnya pada persepsi sesuai kebutuhan (Muflih, 2006:97).

\section{G. Zakat, Infaq, Shadaqah}

Ditinjau dari segi bahasa, kata zakat mempunyai beberapa arti, yaitu albarakatu 'keberkahan', al-namaa 'pertumbuhan dan perkembangan', aththaharatu 'kesucian', dan ash-shalahu 'keberesan'. Sedangkan secara istilah, zakat adalah bagian dari harta dengan persyaratan tertentu, yang Allah SWT mewajibkan kepada pemiliknya, untuk diserahkan kepada yang berhak menerimanya, dengan persyaratan tertentu pula (Hafidhuddin, 2002:7).

Infaq berasal dari kata anfaqa yang berarti menafkahkan atau membelanjakan. Dalam istilah syar'i, infaq berarti mengeluarkan sebagian harta yang kita miliki atau pendapatan yang kita peroleh untuk tujuan yang sejalan dengan syariat Islam (Gaus, 2008:20). Sedangkan sedekah berasal dari kata shadaqa yang berarti benar. Orang yang suka bersedekah adalah orang yang benar pengakuan imannya. Menurut istilah, sedekah adalah suatu pemberian yang diberikan oleh seorang muslim kepada orang lain secara spontan dan sukarela tanpa dibatasi oleh waktu dan jumlah tertentu (Gaus, 2008:21).

\section{H. Hubungan Komunikasi Pemasaran Terpadu dengan Niat Beli Konsumen}

Komunikasi pemasaran atau promosi merupakan aktivitas yang menyampaikan manfaat produk dan membujuk pelanggan untuk membelinya. Shimp (2003:180) mengatakan bahwa para komunikator pemasaran mengarahkan usaha mereka untuk mempengaruhi kepercayaan, sikap, reaksi emosional, dan pilihan-pilihan konsumen yang berhubungan dengan merek. Pada komunikasi pemasaran terdapat konsep yang secara umum sering digunakan untuk menyampaikan pesan disebut sebagai bauran promosi atau disebut juga bauran komunikasi pemasaran yang terdiri dari periklanan, promosi penjualan, hubungan masyarakat, penjualan personal, dan pemasaran langsung.

Dengan banyaknya saluran penghantaran pesan kepada pelanggan dan prospek, hal ini semakin penting bagi perusahaan untuk mengadopsi konsep komunikasi pemasaran terpadu (Integrated Marketing Communication- 
IMC). Konsep komunikasi pemasaran terpadu menurut Kotler dan Armstrong (2008:120) adalah mengintegrasikan dan mengkoordinasikan berbagai saluran komunikasi perusahaan utuk menghantarkan pesan yang jelas, konsisten, dan menarik tentang organisasi dan produknya. Menurut Shimp (2003:161) pada dasarnya komunikasi pemasaran mempunyai tujuan untuk :

a. Membangkitkan keinginan terhadap kategori produk.

b. Menciptakan akan kesadaran akan merek, mendorong sikap positif, dan mempengaruhi niat membeli.

c. Memfasilitasi pembelian.

Dalam penelitian ini hanya menggunakan empat bauran komunikasi pemasaran, karena Yayasan Nurul Hayat cabang Tuban melakukan promosi melalui periklanan, hubungan masyarakat, pemasaran langsung, pernjualan personal.

\section{Hipotesis dan Model Analisis}

Hipotesis yang dapat dirumuskan dalam penelitian ini adalah:

1. Komunikasi pemasaran terpadu berpengaruh signifikan terhadap niat muzakki dalam membayar dana zakat, infaq, shadaqah pada Yayasan Nurul Hayat cabang Tuban.

2. Variabel penjualan personal mempunyai pengaruh dominan terhadap niat muzakki dalam membayar dana zakat, infaq, shadaqah pada Yayasan Nurul Hayat cabang Tuban.

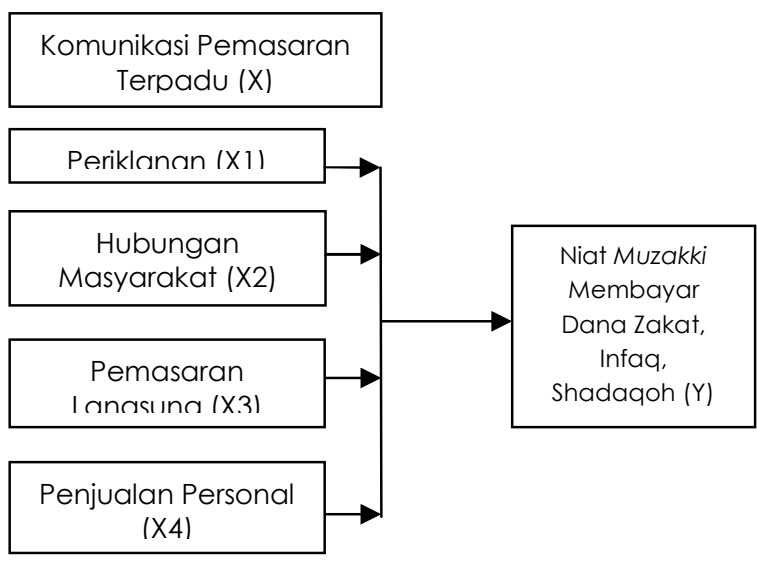

Gambar 1. Model Analisis

\section{METODE PENELITIAN}

Penelitian ini dilakukan dengan menggunakan pendekatan kuantitatif, yaitu dengan melakukkan pengujian hipotesis, pengukuran data dan pembuatan kesimpulan (Suryana, 2010). Penelitian kuantitatif merupakan penelitian yang terstruktur dan mengkuantifikasikan data untuk dapat digeneralisasikan (Anshori dan Iswati, 2009:13).

Variabel yang digunakan dalam penelitian ini terdiri dua variabel, yaitu variabel eksogen adalah bauran dari komunikasi pemasaran terpadu yang terdiri dari:

a) Periklanan (advertising) $\left(X_{1}\right)$

b) Hubungan Masyarakat (Public relation) ( $\left.\mathrm{X}_{2}\right)$

c) Pemasaran Langsung (direct marketing) $\left(\mathrm{X}_{3}\right)$

d) Penjualan personal (personal selling) $\left(X_{4}\right)$

Dan variabel endogennya adalah niat muzakki membayar zakat, infaq, shadaqah (Y). 


\section{A. Definisi Operasional Variabel}

Dalam penelitian ini variabel eksogen terdapat empat variabel komunikasi pemasaran terpadu dengan menerapkan nilai-nilai Islam yaitu sifat-sifat Nabi Muhammad SAW, yaitu shiddia, amanah, tabligh, dan fathanah sebagai key success factors, di antaranya:

a. Periklanan (X1)

$$
\text { Periklanan }
$$

(advertising)

merupakan presentasi non-personal berupa brosur, spanduk, majalah atau media iklan lain yang dilakukan oleh Yayasan Nurul Hayat cabang Tuban untuk mengkomunikasikan jasa yang ditawarkan kepada masyarakat. Indikator yang digunakan dalam variabel periklanan berdasarkan teori dari Kotler dan Armstrong (2008:153) yaitu sebagai berikut:

1. Kemudahan dalam menemukan informasi tentang jasa dan yayasan dari berbagai media.

2. Design iklan dalam berbagai media menarik dan kreatif

3. Pesan iklan yang disampaikan dalam berbagai media adalah benar dan jelas.

4. Pesan iklan yang terkandung dalam berbagai media memiliki daya tarik, dapat dipercaya dan tidak mengandung penipuan.

b. Hubungan Masyarakat (X2)

Hubungan masyarakat dalam penelitian ini adalah program-program yang dirancang oleh Yayasan Nurul Hayat cabang Tuban untuk mempromosikan dan melindungi citra yayasan tersebut.
Indikator yang digunakan untuk mengukur variabel hubungan masyarakat berdasar pada teori dari Kotler dan Armstrong (2008:171) adalah sebagai berikut:

1. Berita yang tersebar mengenai Yayasan Nurul Hayat baik

2. Identitas yayasan berbeda dari yang lainnya

3. Kegiatan pelayanan masyarakat yang dilakukan baik

C. Pemasaran Langsung (X3)

Pemasaran langsung (direct marketing) merupakan penggunaan saluran langsung berupa surat, telepon, email, atau internet yang digunakan Yayasan Nurul Hayat cabang Tuban untuk berkomunikasi langsung dengan konsumen untuk mendapat respon langsung dari konsumen. Indikator yang digunakan untuk mengukur variabel pemasaran langsung berdasar pada teori dari Kotler dan Armstrong (2008:221) adalah sebagai berikut:

1. Penggunaan saluran pemasaran langsung (telepon, sms, website)

2. Komunikasi pihak yayasan dengan muzakki yang interaktif

d. Penjualan Personal (X4)

Penjualan personal merupakan komunikasi pemasaran yang dilakukan Yayasan Nurul Hayat cabang Tuban melalui interaksi tatap muka dengan satu atau lebih konsumen dalam rangka memperoleh tanggapan langsung dari konsumen mengenai jasa yang ditawarkan. Indikator yang digunakan untuk mengukur variabel penjualan 
personal berdasar pada teori dari Kotler dan Armstrong (2008:201) adalah sebagai berikut:

1. Penampilan karyawan baik

2. Karyawan menguasai informasi tentang yayasan dan jasanya

3. Kemampuan karyawan dalam menjelaskan jasa pada konsumen komunikatif dan memuaskan.

Variabel endogen dalam penelitian ini adalah niat beli konsumen dalam penelitian ini adalah niat muzakki membayar zakat, infaq, dan shadaqah adalah kecenderungan muzakki untuk mengambil tindakan untuk membayar zakat, infaq, shadaqah pada Yayasan Nurul Hayat cabang Tuban. Indikator dari variabel niat muzakki membayar zakat, infaq, shadaqah dalam penelitian ini berdasarkan teori dari Kotler dan Armstrong (2008:179) yang disesuaikan dengan konsep mashlahah, antara lain :

1. Kesadaran konsumen akan kebutuhan konsumsi sosial berupa zakat, infaq, shadaqah.

2. Informasi yang diperoleh dari berbagai sumber.

3. Manfaat yang didapat dengan menggunakan jasa disertai dengan persepsi mardhatillah.

4. Merasa suka dengan pelayanan yang diberikan oleh yayasan

5. Lebih menyukai jasa yang ditawarkan yayasan daripada jasa dari lembaga lain.

6. Memiliki keyakinan bahwa pelayanan yang diberikan yayasan adalah yang terbaik.
7. Mendapat kepuasan yang hakiki setelah menggunakan jasa yang ditawarkan

8. Penggunaan jasa kembali atau berulang-ulang

Indikator dari masing-masing variabel tersebut akan diukur melalui jawaban responden atas pertanyaan dalam kuesioner, yang kemudian jawaban tersebut diukur dengan menggunakan skala Likert yang terdiri dari sangat setuju (5), setuju (4), cukup setuju (3), tidak setuju (2), sangat tidak setuju (1).

\section{B. Teknik Pengambilan Sampel}

Penelitian ini menggunakan teknik Simple Random Sampling yaitu pengambilan anggota sampel dari populasi dilakukan secara acak tanpa memperhatikan strata yang ada dalam populasi itu (Sugiyono, 2011:82) Penentuan jumlah sampel dalam penelitian ini ditentukan dengan menggunakan rumus Slovin :

$$
n=\frac{N}{1+N\left(e^{2}\right)}
$$

Berdasarkan data dari Yayasan Nurul Hayat cabang Tuban, jumlah donatur yang membayar zakat, infaq, shadaqah yang tercatat pada tahun 2013 adalah 4.000 donatur, maka dengan menggunakan rumus Slovin diperoleh jumlah sampel sebagai berikut :

$$
\begin{aligned}
& n=\frac{4.000}{1+4.000\left(0,1^{2}\right)} \\
& n=\frac{4.000}{1+4.000(0,01)} \\
& n=97,56 \sim 98 \text { orang }
\end{aligned}
$$




\section{Populasi dan Sampel}

Populasi dalam penelitian ini adalah seluruh muzakki Yayasan Nurul Hayat cabang Tuban. Sedangkan sampel yang digunakan adalah sebagian dari jumlah muzakki Yayasan Nurul Hayat cabang Tuban.

\section{Uji Validitas dan Reliabilitas}

Sebuah instrumen dikatakan valid apabila mampu mengukur apa yang diinginkan. Pengujian validitas pada penelitian ini menggunakan rumus corrected item-total correlation, suatu item pernyataan dikatakan valid jika corrected item-total correlation ( $r$ hitung) lebih besar dari $r$ tabel (Sarjono dan Julianta, 2013:45).

Instrumen yang reliabel adalah instrument yang apabila digunakan beberapa kali untuk mengukur objek yang sama, akan menghasilkan data (Ukuran) yang sama dan akan menghasilkan data yang dipercaya (Anshori dan Iswati, 2009:75). Pendekatan yang digunakan untuk mengukur reliabilitas dalam penelitian ini adalah dengan menghintung Alpha Cronbach (a). Suatu kuesioner dikatakan reliabel jika nilai Alpha Cronbach (a) $\geq 0,6$ (Sarjono dan Julianta, 2013:45).

\section{E. Teknik Analisis Data}

Dalam penelitian ini terdapat lebih dari satu variabel bebas, maka teknik analisis yang digunakan dalam penelitian ini adalah Regresi Linier Berganda. Bentuk persamaan regresi dapat dirumuskan sebagai berikut:

\section{$Y=a_{0}+\beta_{1} X_{1}+\beta_{2} X_{2}+\beta_{3} X_{3}+\beta_{4} X_{4}+e$}

Dimana :

$$
\begin{aligned}
& Y=\text { Nlat Konsumen } \\
& a_{0}=\text { Konstanta } \\
& X_{1}=\text { Iklan (advertising) } \\
& X_{2}=\text { Hubungan Masyarakat (Public } \\
& \text { relation) } \\
& X_{3}=\text { Pemasaran Langsung (direct } \\
& \quad \text { marketing) } \\
& X_{4}=\text { Penjualan Personal (personal } \\
& S_{\text {selling) }} \\
& \beta_{1 . .} \beta_{4}=\text { Koefisien Regresi } \\
& e \quad=\text { Error Term/ varibel pengganggu }
\end{aligned}
$$

\section{HASIL DAN PEMBAHASAN}

\section{A. Uji Validitas dan Uji Reliabilitas}

Uji validitas merupakan suatu

\begin{tabular}{|c|c|c|c|c|}
\hline Variabel & $\begin{array}{l}\text { Ite } \\
\text { m }\end{array}$ & $\begin{array}{c}\text { Correct } \\
\text { ed } \\
\text { Item- } \\
\text { Total } \\
\text { Correlat } \\
\text { ion }\end{array}$ & r Tabel & $\begin{array}{c}\text { Keteran } \\
\text { gan }\end{array}$ \\
\hline \multirow{4}{*}{$\begin{array}{l}\text { Periklanan } \\
(\mathrm{X} 1)\end{array}$} & $X_{1.1}$ & 0,384 & 0,1671 & Valid \\
\hline & $X_{1.2}$ & 0,578 & 0,1671 & Valid \\
\hline & $X_{1.3}$ & 0,558 & 0,1671 & Valid \\
\hline & $\mathrm{X}_{1.4}$ & 0,390 & 0,1671 & Valid \\
\hline \multirow{3}{*}{$\begin{array}{l}\text { Hubungan } \\
\text { Masyarakat } \\
\text { (X2) }\end{array}$} & $X_{2.1}$ & 0,425 & 0,1671 & Valid \\
\hline & $\mathrm{X}_{2.2}$ & 0,474 & 0,1671 & Valid \\
\hline & $X_{2.3}$ & 0,474 & 0,1671 & Valid \\
\hline \multirow{2}{*}{$\begin{array}{l}\text { Pemasaran } \\
\text { Langsung } \\
\text { (X3) }\end{array}$} & $X_{3.1}$ & 0,569 & 0,1671 & Valid \\
\hline & $X_{3.2}$ & 0,569 & 0,1671 & Valid \\
\hline \multirow{3}{*}{$\begin{array}{l}\text { Penjualan } \\
\text { Personal } \\
(\mathrm{X} 4)\end{array}$} & $X_{4.1}$ & 0,475 & 0,1671 & Valid \\
\hline & $\mathrm{X}_{4.2}$ & 0,732 & 0,1671 & Valid \\
\hline & $\mathrm{X}_{4.3}$ & 0,675 & 0,1671 & Valid \\
\hline \multirow{3}{*}{$\begin{array}{l}\text { Niat } \\
\text { Muzakki (Y) }\end{array}$} & $Y_{1}$ & 0,369 & 0,1671 & Valid \\
\hline & $Y_{2}$ & 0,442 & 0,1671 & Valid \\
\hline & $Y_{3}$ & 0,516 & 0,1671 & Valid \\
\hline
\end{tabular}
ukuran yang menunjukkan tingkat kesahihan suatu instrument. Sebuah instrument dikatakan valid apabila mampu mengukur apa yang diinginkan, sehingga dapat mengungkap data dari variabel yang diteliti secara tepat (Anshori dan Iswati, 2009:83).

\section{Tabel 1}

\section{Hasil Uji Validitas Masing-Masing} Indikator 


\begin{tabular}{|c|c|c|c|c|}
\hline \multirow{1}{*}{} & $Y_{4}$ & 0,387 & 0,1671 & Valid \\
\cline { 2 - 5 } & $Y_{5}$ & 0,540 & 0,1671 & Valid \\
\cline { 2 - 5 } & $Y_{6}$ & 0,619 & 0,1671 & Valid \\
\cline { 2 - 5 } & $Y_{7}$ & 0,466 & 0,1671 & Valid \\
\cline { 2 - 5 } & $Y_{8}$ & 0,513 & 0,1671 & Valid \\
\hline
\end{tabular}

Sumber : Data Primer, 2014

Suatu item pernyataan dikatakan valid jika corrected item-total correlation ( $r$ hitung) lebih besar dari $r$ tabel dan bernilai positif. Tabel 1 menunjukkan bahwa seluruh item pernyataan mempunyai nilai validitas yang lebih besar dari $r$ tabel yaitu 0,1671, maka seluruh item dinyatakan valid.

Tabel 2

Hasil Uji Reliabilitas

\begin{tabular}{|c|c|c|}
\hline Variabel & $\begin{array}{c}\text { Alpha } \\
\text { Cronbach } \\
\text { (a) }\end{array}$ & Keterangan \\
\hline $\begin{array}{c}\text { Periklanan } \\
\text { (X1) }\end{array}$ & 0,687 & Reliabel \\
\hline $\begin{array}{c}\text { Hubungan } \\
\text { Masyarakat } \\
\text { (X2) }\end{array}$ & 0,641 & Reliabel \\
\hline $\begin{array}{c}\text { Pemasaran } \\
\text { Langsung } \\
\text { (X3) }\end{array}$ & 0,719 & Reliabel \\
\hline $\begin{array}{c}\text { Penjualan } \\
\text { Personal (X4) }\end{array}$ & 0,783 & Reliabel \\
\hline $\begin{array}{c}\text { Niat Muzakki } \\
\text { (Y) }\end{array}$ & 0,776 & Reliabel \\
\hline
\end{tabular}

Sumber : Data Primer, 2014

Suatu item pernyataan dinyatakan reliabel jika nilai Alpha Cronbach (a) > 0,6. Tabel 2 menunjukkan bahwa masingmasing indikator dalam setiap variabel memiliki nilai Alpha Cronbach (a) > 0,6. Dengan demikian variabel-variabel tersebut dapat dinyatakan reliabel dan selanjutnya dapat digunakan dalam penelitian.

Analisis regresi linier berganda digunakan untuk mengetahui ketergantungan suatu variabel endogen pada lebih dari satu variabel eksogen. Analisis regresi dalam penelitian ini menghasilkanhasil regresi sebagai berikut :

Tabel 3

Hasil Uji Regresi Linier Berganda

\begin{tabular}{|c|c|c|c|}
\hline Variabel & $\begin{array}{c}\text { Koef. } \\
\text { Regresi }\end{array}$ & $\begin{array}{c}\mathbf{t} \\
\text { hitung }\end{array}$ & Signifikan \\
\hline Konstanta & 12,303 & 4,396 & 0,000 \\
\hline Periklanan & 0,481 & 3,080 & 0,003 \\
\hline $\begin{array}{c}\text { Hubungan } \\
\text { Masyarakat }\end{array}$ & 0,624 & 3,018 & 0,003 \\
\hline $\begin{array}{c}\text { Pemasaran } \\
\text { Langsung }\end{array}$ & 0,302 & 1,267 & 0,208 \\
\hline $\begin{array}{c}\text { Penjualan } \\
\text { Personal }\end{array}$ & 0,133 & 0,921 & 0,360 \\
\hline $\begin{array}{l}\text { R }=0,590 \\
\text { R Square }=0,348 \\
\text { Adjusted R Square }=0,319 \text { Signifikasi }=0,000\end{array}$ \\
\hline
\end{tabular}

Sumber : Hasil Output SPSS, 2014

Analisis regresi dalam penelitian ini menghasilkan model regresi sebagai berikut:

\section{$Y=12,303+0,481 X_{1}+0,624 X_{2}+0,302 X_{3}+0,133 X_{4}$}

Setelah dilakukan analisis regresi tersebut dapat diketahui bahwa nilai $\mathrm{R}^{2}$ sebesar 0,348 yang artinya besarnya pengaruh komunikasi pemasaran terpadu yang terdiri dari periklanan, hubungan masyarakat, pemasaran langsung, dan penjualan perorangan terhadap niat muzakki adalah sebesar 34,8\%, sedangkan sisanya sebesar $65,2 \%$ dipengaruhi oleh variabel lain yang tidak dimasukkan dalam penelitian. Berdasarkan hasil penelitian di lapangan, responden membayar ZIS pada yayasan tersebut ada yang dipengaruhi oleh faktor lain di luar bauran komunikasi pemasaran yang dilakukan, faktor lain tersebut seperti faktor lokasi, faktor produk dalam hal ini program-program sosialnya, faktor pendistribusian ZIS, dan faktor dari 
perilaku muzakki secara pribadi yang dipengaruhi faktor budaya, sosial, pribadi, dan psikologis. Sedangkan korelasi antar variabel dapat dinyatakan memiliki hubungan cukup erat, karena nilai $R$ menunjukkan angka 0,590 maka komunikasi pemasaran terpadu yang dilakukan oleh Yayasan Nurul Hayat Tuban cukup erat hubungannya dengan niat muzakki membayar ZIS pada yayasan tersebut. Nilai koefisien regresi dari setiap variabel eksogen memiliki nilai positif, ini berarti bahwa semakin meningkatnya nilai dari tiap variabel eksogen maka meningkat pula nilai dari variabel endogen dalam model regresi tersebut.

\section{B. Uji Hipotesis Simultan}

Hasil regresi tersebut menunjukkan nilai $F$ adalah sebesar 12,384 dengan nilai signifikansi sebesar 0,000 . Nilai signifikansi tersebut lebih kecil dari 0,1 maka komunikasi pemasaran terpadu yang dilakukan oleh Yayasan Nurul Hayat Cabang Tuban secara simultan telah mempengaruhi niat muzakki membayar zakat, infaq, dan shadaqah pada yayasan tersebut. Maka pernyataan hipotesis pertama diterima.

Menurut Shimp (2003:24) salah satu ciri utama dalam Integrated Marketing Communication (IMC), adalah mempengaruhi perilaku. Tujuan IMC adalah untuk mempengaruhi perilaku khalayak sasarannya. Hal ini berarti komunikasi pemasaran harus melakukan lebih dari sekedar mempengaruhi kesadaran merek atau memperbaiki perilaku konsumen terhadap merek. Kesuksesan IMC membutuhkan usahausaha komunikasi yang diarahkan kepada peningkatan beberapa bentuk respon dari perilaku konsumen, dengan kata lain tujuannya adalah untuk menggerakkan orang untuk bertindak.

Dari definisi tersebut dapat disimpulkan bahwa komunikasi pemasaran terpadu dibutuhkan oleh Yayasan Nurul Hayat Tuban untuk mempengaruhi konsumen dalam hal ini adalah muzakki agar berniat membayar zakat, infaq, shadaqah. Dengan komunikasi pemasaran yang baik dapat meningkatkan niat muzakki dalam membayar zIS dan juga dapat membangun kepercayaan para muzakki pada yayasan tersebut.

\section{Uji Hipotesis Parsial}

Variabel perikalanan $\left(X_{1}\right)$ pada hasil analisis regresi memiliki nilai koefisien yang positif yaitu sebesar 0,481 dan hasil uji $\dagger$ menunjukkan nilai signifikansi sebesar $0,003 \leq 0,1$, sehingga dapat disimpulkkan bahwa variabel periklanan memiliki pengaruh yang signifikan terhadap niat muzzakki secara parsial. Adanya pengaruh periklanan terhadap niat muzakki sesuai dengan teori dari Machfoedz (2005:85) bahwa iklan dibuat menarik perhatian dan mudah diiingat dengan tujuan untuk memengaruhi orang agar membeli barang atau jasa tertentu. Informasi yang disampaikan dalam iklan harus jelas. Dalam surat Al-Hujurat ayat 6 , AllahSWT berfirman: 


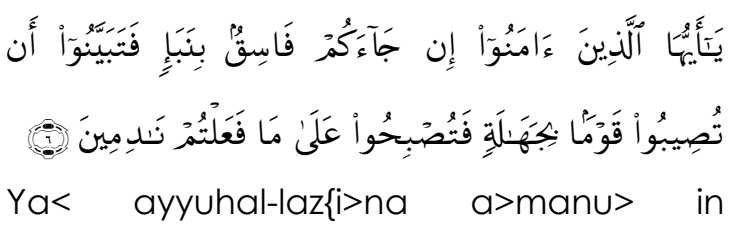
ja>akum

fa>siqum-binabain

fatabayyanu> an-tus\{ibu>qaumam-

bijaha>latin fatus\{bih\{u> 'ala> ma> fa'altum na>dimi>n.

"Hai orang-orang yang beriman, jika datang kepadamu orang Fasik membawa suatu berita, Maka periksalah dengan teliti agar kamu tidak menimpakan suatu musibah kepada suatu kaum tanpa mengetahui keadaannya yang menyebabkan kamu menyesal atas perbuatanmu itu."(Departemen Agama, 2007:516).

Berdasarkan hasil penelitian ini, periklanan yang dilakukan oleh Yayasan Nurul Hayat Tuban melalui berbagai media berhasil menarik perhatian muzakki untuk membayar zakat, infaq, shadaqah pada yayasan tersebut. Informasi dan pesan yang disampaikan pada media periklanan yang dilakukan oleh yayasan jelas, akurat, tidak berlebihan, mudah dipahami, dan dapat dipercaya.

Variabel hubungan masyarakat $\left(X_{2}\right)$ pada hasil uji $\dagger$ menunjukkan nilai signifikansi sebesar $0,003 \leq 0,1$, sehingga dapat disimpulkkan bahwa variabel hubungan masyarakat memiliki pengaruh yang signifikan terhadap niat muzzakki secara parsial. Menurut Maisya (2013) bahwa komunikasi dengan masyarakat melalui hubungan masyarakat dapat mempengaruhi kesan konsumen terhadap sebuah perusahaan atau organisasi maupun produk atau jasa yang ditawarkan. Dalam Islam, Rasulullah SAW dalam melakukan kegiatan pemasaran, beliau selalu membangun silaturahim atau membangun relasi dengan para konsumennya. Dalam suatu hadits Rasulullah bersabda(Suyanto:2008) :

عَنْ أَنَسِ بْنِ مَالِلكٍ رَضِيَ اللهُ عَنْهُ قَالَ سَمِعْتُ رَسُولَ اللهِ

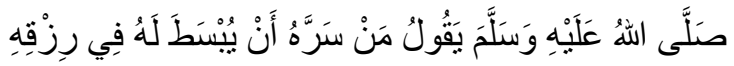

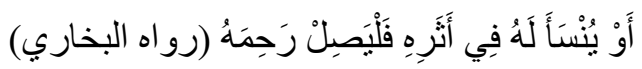
'an 'anasibni ma>liki rad\{iyal-lla>hu 'anhu qa>la sami'tu raslullhi s\{allal-lla>hu 'alaihi wasallama yaqu>lu man sarrahu 'an yubsat\{a lahu fi> rizqihi 'au yunsa' alahu fi> 'as | arihi falyas\{il rah\{imahu.

"Dari Anas bin Malik radliallahu 'anhu berkata; Aku mendengar Rasulullah shallallahu 'alaihi wasallam bersabda: Siapa yang ingin diluaskan rezeqinya atau meninggalkan nama sebagai orang baik setelah kematiannya hendaklah dia menyambung silaturrahim."(HR Bukhari).

Berdasarkan hasil penelitian ini hubungan masyarakat yang dilakukan oleh Yayasan Nurul Hayat Tuban melalui berita dan kegiatan-kegiatan pelayanan masyarakat telah mempengaruhi niat muzakki membayar zakat, infaq, shadaqah pada yayasan tersebut, hal ini juga diperkuat dengan nilai beta dari variabel hubungan masyarakat sebesar 0,303 , nilai ini merupakan nilai yang paling tinggi dari keempat variabel eksogen dalam model regresi, berarti variabel hubungan masyarakat merupakan variabel yang dominan di antara variabel 
lain dalam mempengaruhi variabel niat muzakki.

Variabel pemasaran langsung $\left(X_{3}\right)$ dan personal selling $\left(X_{4}\right)$ dalam penelitian ini masing-masing tidak memiliki pengaruh yang signifikan terhadap variabel niat muzakki secara parsial. Variabel pemasaran langsung $\left(X_{3}\right)$ memiliki nilai signifikansi sebesar 0,208 $>0,1$, sehingga tidak ada pengaruh yang signifikan terhadap niat muzakki secara parsial. Hal ini dikarenakan sebagian muzakki berpendapat bahwa komunikasi yang dilakukan pihak yayasan terhadap para muzakki dan donatur lainnya melalui saluran pemasaran langsung kurang interaktif. Selain itu pemasaran langsung melalui telepon pada yayasan tersebut belum maksimal pelaksanaannya karena penawaran jasa penghimpunan dan penyaluran zakat yang dilakukan melalui telepon masih terbatas kepada konsumen yang menggunakan jasa di luar penghimpunan zakat, infaq, shadaqah. Begitu pula pemasaran langsung melalui email dan internet juga kurang mampu mempengaruhi muzakki untuk berniat membayar zakat, infaq, shadaqah dikarenakan sebagian masyarakat jarang mengakses internet. Allah SWT berfirman dalam surat Ibrahim ayat 4 :

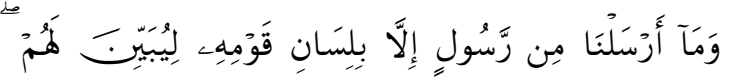

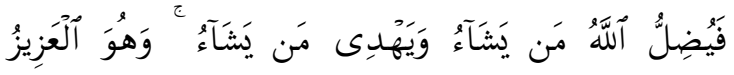

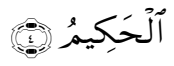

Wama $>$ arsalna $>$ min rasu>lin illa bilisa>ni qaumihi liyubayyina lahum, fayad|illul- llahu man-yasya>', wahuwal-'azi>zulh\{aki>m.

"Kami tidak mengutus seorang rasulpun, melainkan dengan bahasa kaumnya, supaya ia dapat memberi penjelasan dengan terang kepada mereka. Maka Allah menyesatkan siapa yang Dia kehendaki, dan memberi petunjuk kepada siapa yang Dia kehendaki. dan Dia-lah Tuhan yang Maha Kuasa lagi Maha Bijaksana."(Departemen Agama, 2007:255).

Pada variabel penjualan perorangan $\left(X_{4}\right)$ pada hasil uji $\dagger$ menunjukkan nilai signifikansi sebesar $0,360>0,1$, sehingga dapat disimpulkkan bahwa variabel penjualan personal tidak memiliki pengaruh yang signifikan terhadap niat muzzakki secara parsial. Maka pernyataan hipotesis kedua ditolak. Berdasarakan hasil di lapangan, sebagian responden mengatakan bahwa terdapat karyawan Yayasan Nurul Hayat Tuban yang bertugas sebagai advisor zakat kurang komunikatif, selain itu berdasarkan jawaban sebagian responden menganggap bahwa penjualan personal yang dilakukan oleh yayasan tersebut adalah biasa, jadi variabel ini tidak terlalu berpengaruh terhadap niat muzakki membayar zakat, infaq, shadaqah. Allah SWT telah berfirman dalam surat An-Nahl ayat 125 :

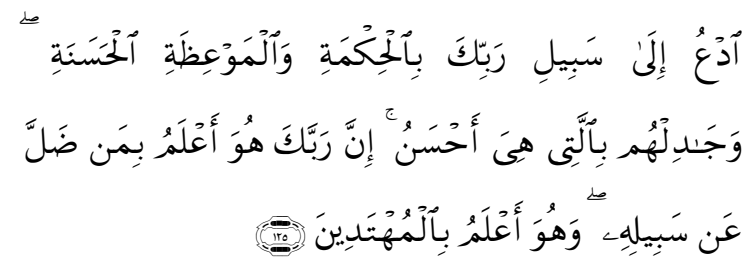


Ud'U il> sabi>li rabbika bil-h\{ikmati walmau'iz\{atil-Ih\{asanati, waja>dilhum billati> hiya ah\{san. Inna rabbaka huwa a'lamu biman d\{alla 'an sabi>lihi, wahuwa a'lamu bil-Imuhtadi>n.

"Serulah (manusia) kepada jalan Tuhanmu dengan hikmah[845] dan pelajaran yang baik dan bantahlah mereka dengan cara yang baik. Sesungguhnya Tuhanmu Dialah yang lebih mengetahui tentang siapa yang tersesat dari jalan-Nya dan Dialah yang lebih mengetahui orangorang yang mendapat petunjuk." (Departemen Agama, 2007:281).

\section{SIMPULAN}

1. Komunikasi pemasaran terpadu yang terdiri dari variabel periklanan, hubungan masyarakat, pemasaran langsung, dan penjualan personal secara simultan berpengaruh terhadap niat muzakki membayar dana zakat, infaq, shadaqah pada Yayasan Nurul Hayat Cabang Tuban dengan nilai F sebesar 12,384 dan nilai signifikansi sebesar $0,000 \leq .0,1$

2. Dari keempat variabel komunikasi pemasaran terpadu, variabel hubungan masyarakat merupakan variabel yang dominan mempengaruhi niat muzakki membayar dana zakat, infaq, shadaqah pada Yayasan Nurul Hayat Cabang Tuban dengan nilai beta sebesar 0,303.

\section{DAFTAR PUSTAKA}

Adisaputro, Gunawan. 2010. Manajemen Pemasaran, Analisis Untuk
Perencanaan Strategi Pemasaran. Yogyakarta : UPP STIM YKPN.

Alam, Syeh Syah. 2011. Is Religiosity an Important Determisnant on Muslim Consumer Behaviour in Malaysia? Journal of Islamic Marketing Vol. 2 No 1

Anshori, Muslih dan Sri Iswati. 2009. Buku Ajar Metode Penelitian Kantitatif. Surabaya : Airlangga University Press

Asmaniah, Yuniati. 2007. Bauran Promosi dalam Perspektif Islam. Skripsi. Malang : UIN Malang

Beik, Irfan Syauqi. 2009. Analisis Peran Zakat dalam Mengurangi Kemiskinan : Studi Kasus Domet Dhuafa Republika. Jurnal Pimikiran dan Gagasan. Vol. II

Departemen Agama RI. 2007. Al-Qur'an dan Terjemahan

Fadhilah, Sri, Nurleli, dkk. 2012. Membangun Kepercayaan Konsumen : Faktor Penting pada Lembaga Amil Zakat Seluruh Indonesia.

Firmansyah, Fani. 2012. Personal Selling Dalam Perspektif Islam . Jurnal Iqtishoduna. Vol 8, No 1

Gaus, Ahmad. 2008. Filantropi dalam Masyarakat Islam. Jakarta: PT Elex Media Komutindo

Hafidhuddin, Didin. 2002. Zakat dalam Perekonomian Modern. Gema Insani : Jakarta

Hendratmi, Achsania. 2013. Komunikasi Bisnis Rasulullah. Slide Perkuliahan Manajemen Pemasaran Syariah. 
Departemen Ekonomi Syariah

Fakultas Ekonomi dan Bisnis

Universitas Airlangga

Kartajaya, Hermawan dan Syakir Sula.

2006. Syariah Marketing. Bandung :

PT Mizan Pustaka

Kotler, Philip dan Gary Armstrong. 2008.

Prinsip-Prinsip Pemasaran. Edisi

Keduabelas Jilid 1 . Jakarta

:Erlangga

Kotler, Philip dan Gary Armstrong. 2008.

Prinsip-Prinsip Pemasaran. Edisi

Keduabelas Jilid 2 . Jakarta

:Erlangga

Kotler, Philip dan Kevin Lane Keller. 2008.

Manajemen Pemasaran Edisi

Ketigabelas Jilid 1. Jakarta :

Erlangga

Kotler, Philip. 2005. Manajemen

Pemasaran. Edisi Kesebelas Jilid

Dua, Jakarta : PT Indeks Kelompok

Gramedia

Machfoedz, Mahmud . 2010. Komunikasi

Pemasaran Modern, Yogyakarta :

Cakra llmu.

Machfoedz, Mahmud. 2005. Pengantar

Pemasaran Modern. Yogyakarta:

PP AMP YKPN

Maisya, Fitri. 2013. Pengaruh Perikalan,

Promosi Penjualan, dan Hubungan

Masyarakat Terhadap Keputusan

Menabung di PT. Bank Negara

Indonesia, Tbk. Cabang Bukit

Tinggi. Jurnal Ilmiah. Padang :

Fakultas Ekonomi Universitas Negeri

Padang.
Maulana, Amalia E. 2010. Pemasaran Sosial: MarCom Gaya LAZ. ETNOMARK

Muflih, Muhammad. 2006. Perilaku Konsumen Dalam Perspektif IImu Ekonomi Islam. Edisi 1. Jakarta : PT Raja grafindo persada

Muslich. 2007. Bisnis Sayari'ah Perspektif Mu'amalah Dan Manajemen. Yogyakarta : UPP STIM YKPN

Nasiha, Sholehatun. 2010. Strategi Komunikasi Pemasaran Terpadu (Integrated Marketing Communication) Dalam Mengkokohkan Brand Dagadu Djokja. Skripsi. Yogyakarta: UIN Kalijaga

Payne, Adrian. 2001. Pemasaran Jasa. Yogyakarta : ANDI

Prasetyo, Eddy. 2013. Pengaruh Iklan, Promosi Penjualan Dan Penjualan Perorangan Terhadap Niat Beli Di Cv. Lancar Makmur Motor Surakarta. AGORA Vol. 1, No. 3

Rachmad, Edi. 2013. Efektivitas Komunikasi Perspektif Islam. www.waspadamedan.com.

Diakses pada 25 November 2013

Sari, Novita. 2009. Komunikasi Pemasaran Produk Pembiayaan Dana Talangan Haji Pada Bank Syariah Mandiri Cabang Malang. Sripsi. Malang : Universitas Islam Negeri Maulana Malik Ibrahim

Sarjono, Haryadi dan Winda Julianita. 2013. SPSS VS LISREL : Sebuah Pengantar, Aplikasi untuk 
Riset.Jakarta : Penerbit Salemba

Empat

Shimp, Terrence A. 2003. Periklanan

Promosi Dan Aspek Tambahan

Komunikasi Pemasaran Terpadu,

Edisi Ke-5 Jilid 1. Jakarta : Erlangga

Soemanagara, Rd. 2006. Strategic

Marketing Communication Konsep

Strategis dan Terapan. Bandung :

Alfabeta

Sugiyono. 2011. Metode Penelitian

Kuantitatif, Kualitatif dan R\&D.

Bandung: Alfabeta

Suryana. 2010. Metode Penelitian Model

Praktis Penelitian Kuantitatif dan

Kualitatif. Bandung: Universitas

Pendidikan Indonesia

Suyanto. 2008. Strategi Promosi Nabi SAW.

Artikel. Yogyakarta : STMIK

AMIKOM

Yudhiartika, Dian dan Jony Oktavian Haryanto. 2012. Pengaruh Personal Selling, Display, Promosi Penjualan Terhadap Kesadaran Merek Dan Intensi Membeli Pada Produk Kecantikan Pond's. Buletin Studi Ekonomi,Volume 17, No. 2 